\title{
Can Wearables Measure Aesthetic Responses to Fashion Products?
}

\author{
Jisoo Park \\ Research Institute of Human Ecology, Seoul National University, Seoul, Korea
}

Corresponding author: Jisoo Park, Research Institute of Human Ecology, Seoul National University, 1 Gwanak-ro, Gwanakgu, Seoul 08826, Korea

Tel.: +8228806806

Fax: +82 28791976

Email: jissoo@snu.ac.kr

Received August 30, 2019

Revised December 5, 2019

Accepted December 6, 2019

Published December 30, 2019

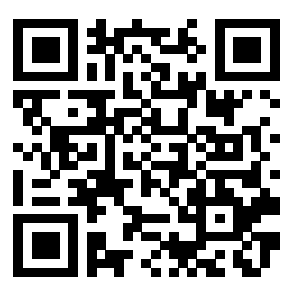

\begin{abstract}
Purpose: This study explores the potential of wearables as a new tool for measuring consumer response to products by quantitatively measuring the physiological responses to the aesthetical differences (high vs. low) on the basis of product appearance; we also examine the correlation between physiological measurements and self-reported responses. Methods: After employing the perfume products as stimulants, we divided them in two groups on the basis of their high and low aesthetic as aspects; furthermore, we randomly assigned participants to one of those two groups. While browsing through the products, participants' heart rates and galvanic skin responses, on the basis of their perceptions of the perfumes' aesthetics, were measured with wearables. We also gathered the participants' responses through self-reported surveys. Results: Differences in heart rate and heart rate variability in response to perceived aesthetics were not statistically significant. However, we did observe an interaction between product preferences and perceived aesthetics. Products with high aesthetics and personal preferences as revealed through the surveys induced greater heart rate variability: such products also tended to cause more galvanic skin responses. Among the physiological data, skin electro-conductivity was found to have the strongest correlation with the subjective assessment of perceived aesthetics. Conclusion: We confirmed that physiological responses differ in accordance with the aesthetical levels of product appearance and are consistent with self-reported perceived aesthetics. These results can be expanded to various product groups and employed to perform marketing to consumers.
\end{abstract}

Keywords: Aesthetics, Wearables, Heart rate, Galvanic skin response, Physiological response

\section{Introduction}

현대 제품에서는 기능이나 편리성보다 감성적 가치가 강조되고 있다. 기술에 의한 제품 차별화가 어려워짐에 따라 소비자의 감성 적 가치를 자극하여 니즈를 만족시키고, 신념과 태도를 형성하도록 하여 궁극적으로 제품 구매의사결정에 영향을 미칠 수 있기 때문이 다(Bloch, 1995). 이에 제품 외관에서 아름다움이나 매력을 느끼는 심미성 지각(Yang \& Hong, 1999)의 중요성이 대두되었다. 관련 업계는 물론 학계에서도 이를 인지하여, 심미성을 유발하는 디자인 요소를 규명하는 연구에서 심미성 지각 이후의 소비자 반응 메커니 즘을 밝히는 연구에 이르기까지 다양한 연구가 수행되었다.
그간의 연구결과들을 살펴보면, 심미적 제품은 소비자가 대 안 집합을 형성하는 단계에서부터 시작하여(Garber, 1995; Underwood, 2003), 평가 단계에 이르기까지 영향을 주는 것으로 알려져 있다(Kwak et al., 2011). 또한 소비자로 하여금 감정적, 지적, 사회적 가치를 크게 지각하도록 하여 제품 구매의도(Ju \& $\mathrm{Koo}, 2014)$, 사용자 만족이나 기업 이미지에도 긍정적 영향을 미 치며(Kang, 2016), 충성을 이끌어 내기도 한다(Kim, 2013). 이 러한 연구결과는 미적 가치가 강조되는 제품은 물론 IT 제품과 같 이 기능성이 강조되는 제품을 대상으로 하여도 일관된 경향을 보 인다. 특히 패션이나 뷰티 제품에서 제품 디자인과 로고 등 시각 적 이미지는 품질에 대한 기대를 높이고(Lim, 2016; Lee \& Min, 
2015), 제품 차별화의 단서로 작용하거나(Lee \& Lim, 2012), 특 정 국가 제품에 대한 신뢰를 형성하는 바탕이 되기도 한다(Jeong $\& \mathrm{Seo}, 2016)$. 이러한 현상은 2,30 대 소비자는 물론 50 대 소비 자에서도 관찰되며(Lee \& Park, 2014), 제품 디자인을 강조하는 고가 뷰티 제품뿐 아니라 저가 화장품의 구매행동에서도 나타난다 (Lee, 2016).

심미적인 제품 디자인이 긍정적인 반응을 이끌어내는 일종의 심 리적 기제로 작용하는 원인에 대해 Lee (2013)는 뷰티프리미엄 (beauty premium) 현상이 사물에 대해서도 일어나기 때문이라고 하였다. 매력적인 외모를 가진 사람이 사회적으로 바람직한 다른 특성도 갖추고 있다고 인식되는 것처럼, 아름다운 제품은 사용 용 이성, 제품 구매 의도, 만족, 브랜드나 기업 이미지 평가에 도움을 준다는 것이다.

그러나 연구의 한계점은 존재하며, 특히 심미성 지각의 측정 문 제가 많은 관심을 받고 있다. 그간 이용된 방식은 주로 자기 기입 식(self-reported) 설문이었다. 이 방식은 문항이 완성되면 응답 자를 통해 바로 자료를 수집할 수 있고, 문항의 다양한 변용을 통 해 더 많은 정보를 비교적 쉽게 얻어낼 수 있는 장점이 있다. 이로 인해 제품은 물론 점포(Lee et al., 2018; Jang et al., 2015), 웹 사이트(Tuch et al., 2010), 커뮤니케이션(Lee et al., 2011) 등 여러 분야에서 심미성 지각 측정에 널리 활용되고 있다. 그러나 응 답에 영향을 미칠 수 있는 개인적, 사회적 요인을 완전히 통제하 기 힘들며(Ravaja, 2004), 응답자가 자신의 느낌이나 기분을 기 억해 내어 심미성을 지각했는지 의식적으로 답해야 하므로(Park, 2011) 응답자들의 기억에 의존해야 한다.

이에 자기 기입식 연구방법의 대안 또는 보완적 수단으로 심리 생리학적 방법론이 주목받고 있다(Lee et al., 2011). 심리생리학 은 인간의 생리적 현상을 통해 감정, 인지, 행동을 설명하는 분야 이다(Cacioppo \& Tassinary, 1990). 심장혈관, 피부, 근육, 뇌, 안 구의 활동 등 신체의 생리적 반응은 의식적으로 통제할 수 없기 때 문에 무의식 상태의 심리적, 감정적 반응을 은밀하게 포착해 낼 수 있다. 이로 인해 개인이 의도적으로 답변의 방향을 정하거나 기억 에 의한 왜곡을 막을 수 있는 유용한 수단으로 평가된다. 소비자 가 제품을 접한 순간 느끼게 되는 초기 감성도 소비자의 생리적 신 호를 이용하여 측정할 수 있는데(Davis, 2003; Lee \& Lee, 2010; Norman, 2005), 실제로 색채 및 색채의 조합이 유발하는 감성도 뇌파를 통해 설명되고 있다(Kim, 2017; Ryu \& Lee, 2015).

감정, 감성의 측정에 활용되는 생리학적 지표로는 뇌전도 (electroencephalogram, EEG), 심전도(electrocardiogram, $\mathrm{ECG}$ ), 심박수(Heart Rate, HR), 피부전기활동(galvanic skin response, GSR), 안면근전도 (facial electromyogram, facial $\mathrm{EMG}$ ) 등이 있다. 이중 심박수와 피부전기도는 비교적 측정이 간 편한 도구들이 개발되어 있고(Kim et al., 2010), 신체의 자율신 경계(교감 및 부교감신경)의 활동을 측정할 수 있어 감정의 지표가
된다(Tröndle et al., 2014). 교감신경은 활성, 부교감신경은 안정 및 균형과 관계가 있기 때문에(Thayer et al., 2009). 심박수의 증 가는 감정이 활성화된 각성(arousal) 상태나 미적 반응을 나타내 게 된다(Nakahara et al., 2009).

피부전기도와 그 변산도 감정 활성화의 지표로 이용된다 (Sequeira et al., 2009; Park, 2011). 건조한 상태의 피부는 전 기전도도가 낮은데, 땀이 발생하면 땀에 포함된 소량의 이온이 피 부의 전기전도율을 변화시키기 때문에 감정의 활성화를 측정할 수 있다(Sequeira et al., 2009). 실제로 음악이나 사진 등 시청 각적 심미적 체험은 피부전기활동을 증가시킨다고 알려져 있다 (Koelsch \& Siebel, 2005). 이상을 통해 심박수와 피부전기도 증 가는 제품 외관에 대한 소비자의 심미성 지각 활성화 여부를 나타 내어 감성의 강도를 측정하는 역할을 수행하는 것으로 볼 수 있다.

물론 이 방법에도 단점은 존재한다. 생리적 반응에 개인차가 존 재하며, 일부 생리학적 반응은 비교적 천천히 변화하여 측정에 오 류가 발생할 수 있다. 또한 측정 장비가 상대적으로 고가이고(Lee et al., 2011), 데이터 분석에도 전문지식이 요구되는 경우가 많 다. 디자인 분야에서도 장비 문제로 인해 생리적 측정이 제한되었 음이 보고된 바 있다(Lee \& Lee, 2010).

그러나 최근 웨어러블 기기(wearable device)에 감정이나 심리 상태를 측정하는 기술이 적용됨에 따라 생리학적 지표를 보다 간 편하게 측정할 수 있는 가능성이 열리고 있다. 심장박동, 혈압, 수 면 패턴, 걸음 수의 측정에서 나아가, GSR 센서를 이용하여 피부 의 온도와 전기신호를 측정할 수 있는 기기가 출시되었으며(Nam, 2016), 안정 상태에서는 의료기기 수준으로 심박수를 측정할 수 있는 맥박 센서도 개발되고 있다(Lee et al., 2018). 의학, 운동생 리학 분야의 웨어러블 연구에서는 기존의 생리학적 측정 기기를 대신할 수 있는 웨어러블의 가능성을 탐색하고 있다. 임상 의학용 심전도를 웨어러블 심전도로 대체할 수 있음을 밝히거나(Lee et al., 2018), 의복 형태의 웨어러블 시스템이나(Koo et al., 2015) 손목 밴드 형태의 웨어러블의 측정 타당도와 신뢰도를 검증하는 연구들이 그 예이다(Nam, 2016).

그러나 제품에 대한 심미성 반응을 웨어러블 기기로 측정하려는 시도는 미미한 실정이다. 개인의 취향과 기호를 반영하는 패션 제 품이나 뷰티 제품에 있어 심미성은 초기 감성을 좌우하며 제품 평 가에 큰 영향을 미치기 때문에 심미성 반응 측정은 전략적으로 매 우 중요하다. 또한 웨어러블 기기 착용이 일상화되고 있음을 고려 할 때 소비자 반응을 측정할 수 있는 유용한 도구로서 웨어러블 기 기의 활용 방안을 다각도로 파악할 필요가 있다.

이에 본 연구에서는 제품에 대한 심미성 반응을 측정함에 있어 웨어러블이라는 새로운 측정도구의 가능성을 모색하여 활용방안 을 제시하고자 한다. 구체적으로, 소비자와 제품의 접점에서 제품 의 심미성 수준에 따른 심박수와 피부전기 반응을 웨어러블 기기 로 측정하고, 이 데이터를 자기기입식 측정치와 비교하여 웨어러 
블 기기의 활용 가능성을 제안하고자 한다.

본 연구를 통해 연구자가 보다 쉽게 활용할 수 있는 새로운 생리 적 데이터 측정방법을 제시함으로써 제품 디자인 및 개발 분야의 연구를 확장하는 데 기여할 수 있을 것이다. 또한 패션 및 뷰 뷰티 산업 등 제품을 생산하는 산업 현장에서 소비자에 대한 심층적 이 해를 바탕으로 제품을 기획하고 마케팅 전략을 수립하는 데 활용 할 수 있을 것이다.

\section{Methods}

본 연구의 주목적은 소비자가 지각하는 제품의 심미성을 웨어러 블 기기라는 새로운 측정 도구를 통해 확인할 수 있는 지 탐색하는 것이다. 이를 위해 실험연구를 진행하였다. 먼저 제품 자극물을 개 발하고, 제품 자극물에 대한 연구 참가자들의 심미성 반응을 웨어 러블 기기와 자기기입식 설문지로 측정하였으며, 두 측정치를 비 교하는 과정을 거쳤다.

\section{1. 자극물 개발}

자극물로 사용될 제품의 종류는 다양한 디자인이 존재하며, 쾌 락적 평가 기준이 주로 적용되는 제품군 중에서 사전 검증을 통해 선정하였다. 쾌락적 평가(e.g., 스타일, 색채)가 주를 이루는 제품 은 심미성과 같은 정서적 반응과 관련되며(Lim \& Park, 1999), 실 용적 기준(e.g., 기능성, 내구성)이 평가의 주를 이루는 제품에 비 해 제품의 외관에 더 주목하게 하는 효과가 있다고 판단되었기 때 문이다. 본 연구에서는 선행연구를 통해 뷰티 제품인 향수를 실험 자극물로 이용하였다(Patrick \& Hagtvedt, 2011; Song \& Lee, 2017). 소비자가 화장품을 선택하는 데 있어 심미성이 중요한 기 준으로 작용함이 다수의 선행연구를 통해 입증되었으며, 향수는 기 능성보다는 향과 외관의 아름다움이라는 쾌락적, 심미적 기준이 특 히 중요한 제품군이기 때문이다.

자극물은 심미성의 높고 낮은 정도로 구분하여 제시되어야 하므 로 이에 대한 조작이 필요하였다. 특히 향수 제품에 대해 소비자는 시각적으로 조화로우면서도 독특한 제품에서 무의식적, 감정적으 로 즐거움을 느끼기 때문에(Yang \& Hong, 1999; Ju, 2012), 제 품 디자인의 독특성으로 심미성의 높고 낮음을 조작하였다.

자극물 선정을 위해 우선 연구자가 인터넷 검색을 통해 향수 제 품 사진을 수집한 후, 5 명의 패션 전공 대학원생들이 이를 평가하 게 하였다. 연구의 외적 타당성을 높이기 위해 자극물은 공신력 이 보장된 전문 매체인 WWD와 다양한 제품 구색을 갖추고 있는 전문 쇼핑몰 퍼품닷컴(perfume.com), 세포라(sephora), 프래그 런스엑스(fragrancex)에서 여성 향수 제품을 1 차 수집하였다. 이 후 대학원생들이 각각의 제품에 대해 제품의 균형미, 조화, 독특 성, 심미성을 5 점 리커트 척도로 평가하였고, 4 개 문항의 평균을
구하여 점수가 극단적으로 낮은 제품들과 높은 제품들을 추려 내 어 심미성이 높은 제품과 낮은 제품으로 분류하였다. 평가의 개인 차를 배제하기 위해 추려낸 제품들 중 평균 점수의 분산이 큰 제품 들을 제외하여, 최종적으로 심미성이 높은 향수 16 종과 심미성이 낮은 향수 16종을 제품 자극물로 선정하였다. Iyengar \& Lepper (2000)의 연구에서는 24 개와 6 개의 제품 선택 상황 중 제품 수가 24 개일 때 정보과부하 현상을 관찰하였으며, Bollen et al. (2010) 은 소비자가 10 개 내외의 아이템을 평가하는 것이 이상적이라 제 안한 바 있다. 따라서 본 연구에서 제시하는 자극물의 수가 소비자 의 판단에 영향을 주지 않아 생리학적 데이터 수집에 문제가 없을 것이라 판단하였다.

제품 외관의 독특성은 형태와 색채 측면에서 나타날 수 있는데, 향수 패키지의 특성상 색채의 영향이 크고(Song \& Lee, 2017), 선호하는 컬러에 따라 인체 생리신호의 반응이 달라질 수 있다(Jin et al., 2011). 본 연구에서는 연구 결과 해석의 혼란을 예방하기 위해 색채의 영향력을 최소화하여 형태에서 지각되는 심미성에 초 점을 맞추었다. 이에 따라 최종 선택된 자극물을 흑백 일러스트로 변환하여 사용하였다.

\section{2. 실험 및 자료 수집}

실험은 패션 또는 뷰티 제품을 온라인으로 쇼핑한 경험이 있는 2,30 대 여성을 대상으로 실시되었다. 실험 참가자는 웨어러블 기기 (Sleepman; Avantechs Inc, USA)를 착용한 상태에서 온라인 매장 에서 제품을 둘러본 후 설문에 응답하는 과정을 거치기 때문에 인 터넷 및 모바일 사용 환경에 익숙해야 한다. 따라서 온라인 쇼핑 경 험자로 대상을 한정하였다. 또한 자극물이 여성 향수 제품임을 고 려할 때 심미성 평가에 남녀 간 차이로 생길 수 있는 불필요한 노이 즈를 없애고 실제 소비자의 반응을 반영하기 위해 여성으로 한정하 여 60 명을 모집하였다. 본 연구는 서울대학교 연구윤리위원회의 승 인을 받았으며, 모든 피험자에게 실험 내용을 충분히 설명하고 동 의를 구한 후 진행되었다(승인번호: 1805/001-006).

실험 참가자가 도착하면 실험에 대해 안내한 후 실험동의서를 작 성하도록 하였다. 작성이 끝나면 한쪽 손목에 웨어러블 기기를 착 용하도록 하여 기기와 연동되는 컴퓨터 프로그램을 통해 연구자가 실험 참가자의 생리적 상태를 확인할 수 있도록 하였다. 실험에 이 용된 웨어러블 기기는 심박수와 피부전기반응을 측정할 수 있는, 최근 개발된 Sleepman (Avantechs Inc)을 선정하였다. 부착 후에 는 장비로 인해 부자연스러운 행동을 최소화하고 긴장을 풀 수 있 도록 실험 참가자들에게 3-5 min의 적응 시간을 할애하였다.

실험 참가자는 컴퓨터 스크린을 통해 주어진 시나리오를 읽은 후, 안정된 상태를 유지하는 시간을 가진 후 제품을 둘러보는 과 정을 거쳤다. 제시된 시나리오에서는 쇼핑 상황을 가정하며, 새로 운 시즌에 출시된 제품을 둘러보고 마음에 드는 제품을 평가하는 내용으로 구성하였다. 이때 전체 실험 참가자의 반은 심미성이 높 
은 제품을 쇼핑하는 환경에, 나머지 반은 심미성이 낮은 제품을 쇼 핑하는 환경에 무작위로 배정하였다. 실험 참가자들이 제품을 둘 러보지 않고 지나치는 것을 방지하고, 생리적 반응이 일어날 시간 을 충분히 주기 위해 하나의 제품은 $20 \mathrm{~s}$ 이상 스크린에 보여지도 록 하였으며, 제품이 제시되는 순서도 무작위로 조정하였다. 이 과 정에서 측정된 생리학적 반응 데이터를 컴퓨터로 저장, 수집하였 다. 수집한 데이터는 웨어러블 기기로 측정한 심박수와 피부전기 반응이며, 쇼핑에 걸린 총 소요시간과 각 제품 관찰에 소요된 시간 도 측정하였다.

제품을 둘러보는 과정을 마친 참가자들은 자기기입식 설문에 응 답하였다. 둘러본 패션제품들에 대한 미적 평가를 설문문항은 $\mathrm{Na}$ et al. (2017), Kang (2016), Tuch et al. (2010)의 연구를 바탕 으로 제품의 디자인이 '매력적이다', '시각적으로 흥미를 끈다', '세 련되어 보인다', '아름답다', '멋지다'의 5 문항으로 구성하였으며, 7 점 리커트 척도로 측정하였다.

심미성 외에도 실험 참가자의 생리적 반응에 영향을 미칠 가능 성이 있는 패션 관여도와 기술수용도를 추가적으로 측정하였다. 측정 문항은 모두 7점 리커트로 측정하였으며, 각각 Han et al. (2016)과 Shin \& Lee (2015)의 연구를 참고하였다. 자극물 조작 확인을 위해 제시된 제품의 조화와 독특성을 묻는 문항도 측정하 였으며, 제품의 선호가 미치는 영향을 고려하여 선호도를 측정하 였다. 마지막으로 실험 참가자의 연령, 직업, 학력, 소득수준 등 인구통계적 특성을 측정하였다.

\section{3. 자료분석}

수집된 자료는 SPSS 23.0, 프로그램을 이용하여 통계적 검증 을 실시하였다. 자극물에 의한 조작을 확인하고 집단의 동질성을 확보하기 위해 분산분석을 실시하였으며, 측정도구의 신뢰성과 타 당성을 확인하기 위해 탐색적 요인분석과 신뢰도 분석을 실시하 였다. 웨어러블 기기로 측정된 생리적 측정치가 심미성 고저 집단 에 따라 차이를 보이는 지 검증하였으며, 생리적반응의 측정값과 심미성 척도의 상관관계를 분석하여 실험 참가자의 주관적 응답과 생리적 측정치를 비교하였다. 최종적으로 생리적 데이터와 심미성 지각 간 회귀분석을 실시하였다.

\section{Results and Discussion}

\section{1. 실험참가자 특성}

실험 참가자의 성별과 연령을 한정한 결과, Table 1 에서와 같이 20 대와 30 대가 각각 42 명(70\%), 18명(30\%)로 나타났으며, 6 명 을 제외한 실험 참가자가 모두 미혼 이었다. 직업에 따른 분류에서 는 학생이 가장 많은 비중을 차지하였고, 다음으로 사무직이 분포 되어 있었다. 학력에 있어서는 대학교 재학 이상이 전체의 $95 \%$ 를
차지하였다. 이상을 종합할 때 본 연구의 표본은 대학교 재학 이상 학생이나 사무직에 종사하는 20 대 여성으로 볼 수 있다.

\section{2. 자극물 조작 검증}

본 연구에서 심미성 고저 조작에 사용된 제품들의 독특성을 실 험 참가자들이 어떻게 지각하고 있는지 확인하여 자극물 조작 검 증을 실시하였다. 분산분석을 실시한 결과, Table 2 에서와 같이 심미성 고집단에 배정된 실험 참가자들이 독특성을 더 높게 지각 하는 것으로 나타나(M저집단 $=2.89, \mathrm{SD}$ 저집단=1.02; $\mathrm{M}$ 고집단 $=5.23, \mathrm{SD}$ 고집단 $=1.15 ; F=3.53, p=0.04)$, 자극물 선정이 적절 함을 확인하였다.

\section{3. 심미성 고저에 따른 생리적 반응}

심미성 고저 집단의 심박수와 피부전기도 비교를 위해 각각 분 산분석을 실시하였다. 종속변수는 심박수와 심박수의 변산, 피부 전기도와 피부전기도의 분산이 투입되었다. 심박수는 실험 참가 자 개인의 심박수 시계열 값들을 평균한 심박수 평균으로 구하였 으며, 심박수의 변산은 초기 심박수와 실험 진행중 심박수 최대값 의 차를 사용하였다. 피부전도도 측정값은 실험 동안 측정된 누 적값의 평균을 구하고 다시 전체 실험 참가자의 평균값을 계산 하였으며, 피부전도도의 변산은 초기 피부전도도와 최대값의 진 폭 차이로 구하였다. 측정값은 범위를 일치시키기 위해 정규화 (normalization)하여 사용하였다.

심미성 수준이 서로 다른 두 집단의 심박수에 차이를 보이는지 알아보기 위하여 분산분석을 실시한 결과, 심박수에 대해서는 심 미성이 높은 집단과 낮은 집단의 유의미한 차이가 존재하지 않았 으며 $(F=1.58, p=0.36)$, 심박수 변산에 대해서도 동일한 결과가 도출되었다 $(F=2.39, p=0.21)$. 결과는 Table 3 과 같다.

이에 제품에 대한 선호가 심박수의 변화에 영향을 미치는지 알 아보기 위해 2 차 분석을 실시하였다. 이를 위해 참가자 개인별로 16 개의 제품 자극물을 선호가 높은 자극물 8 개와 낮은 자극물 8 개 를 분류하여 심박수 변산의 차이를 관찰하였다. 즉, 심미성과 선호 가 높은 집단, 심미성과 선호가 모두 낮은 집단, 심미성은 높으나 선호는 낮은 집단, 심미성은 낮으나 선호가 높은 집단의 4 개 집단 으로 나누어 참가자의 심박수와 심박수 변산을 비교하였다. 그 결 과 심박수 변산에서 유의미한 상호작용이 관찰되었다(Table 4). 심 미성 고저에 따라 심박수 변산과 제품에 대한 선호가 달라지지는 않았으나, 심미성과 선호가 모두 높은 집단에서는 심박수 증가 현 상이 나타남을 확인할 수 있었다. 즉, 심미성이 높은 제품에 배정 된 참가자는 자신이 선호하는 형태의 제품을 둘러 볼 때 심박수가 증가하는 경향을 보인 것이다. 이는 미적으로 우수한 제품을 접하 더라도 자신의 취향이나 기호에 맞지 않으면 각성 수준이 상승되 지 않음을 의미한다.

피부전도율을 종속변수로 하여 심미성 수준이 서로 다른 두 집 
단 간 차이를 보이는지 알아보기 위해 분산분석을 실시하였다.

Table 5에서와 같이 제품의 심미성이 높은 집단에 배정된 실험 참
가자들의 피부전도율은( $\mathrm{M}=4.19 \mu \mathrm{m}, \mathrm{SD}=2.13)$ 낮은 집단의 피부 전도율보다 높게 나타났으며( $\mathrm{M}=3.52 \mu \mathrm{m}, \mathrm{SD}=2.80)$, 그 차이는

Table 1. Characteristics of participants

\begin{tabular}{llrr}
\hline Demographic characteristics & Categories & N & $\%$ \\
Age & 20 's & 42 & 70.0 \\
Marital status & 30 's & 18 & 30.0 \\
& Unmarried & 54 & 90.0 \\
& Married & 6 & 10.0 \\
Occupation & Students & 28 & 46.7 \\
& Office jobs & 12 & 20.0 \\
& Professionals & 6 & 10.0 \\
& Freelancers & 5 & 8.3 \\
Academic background & Servie/Sales & 2 & 3.3 \\
& N/A & 7 & 11.7 \\
& High school & 2 & 3.3 \\
& College students & 21 & 35.0 \\
& Graduates & 21 & 35.0 \\
& Graduates, Master's degree, or Ph.D. & 15 & 1.7 \\
\hline
\end{tabular}

Table 2. ANOVA results for stimulant manipulation

\begin{tabular}{lccc}
\hline Item & High in perceived aesthetics & Low in perceived aesthetics & $F$ \\
Perceived uniqueness & $5.23(1.15)^{1)}$ & $2.89(1.02)$ & 3.53 \\
\hline
\end{tabular}

${ }^{1)}$ Mean (standard deviation).

Table 3. ANOVA results for differences in heart rate and variability of heart rate

\begin{tabular}{lcccc}
\hline Item & High in perceived aesthetics & Low in perceived aesthetics & $F$ & $p$ \\
Heart rate & $68.29(5.28)^{1)}$ & $67.32(4.17)$ & 1.58 & 0.36 \\
Variability of heart rate & $4.18(2.19)$ & $3.64(1.96)$ & 2.39 & 0.21 \\
\hline
\end{tabular}

${ }^{1)}$ Mean (standard deviation).

Table 4. ANOVA results for differences in variability of heart rate and preference for high/low products

\begin{tabular}{lccccc}
\hline Source of variation & Sum of squares & df & Mean square & $F$ & 0.15 \\
Variability of heart rate & 0.08 & 1 & 0.08 & 1.20 & 0.70 \\
Preference & 1.58 & 1 & 1.58 & 6.59 & 0.05 \\
$\begin{array}{l}\text { Variability of heart rate } x \\
\text { Preference }\end{array}$ & 11.33 & 1 & 11.33 & 1.59 & \\
Error & 92.33 & 58 & & \\
\hline
\end{tabular}

Table 5. ANOVA results for differences in skin conductance level

\begin{tabular}{lrrr}
\hline Item & High in perceived aesthetics & Low in perceived aesthetics & $F$ \\
Skin conduct level $(\mu \mathrm{m})$ & $4.19(2.13)^{1)}$ & $3.52(2.80)$ & 7.40 \\
\hline${ }^{1)}$ Mean (standard deviation) ${ }^{*} p<0.05$ & & & $0.04^{*}$ \\
\hline
\end{tabular}


통계적으로 유의미하였다 $(F=7.4, p=0.04)$.

심미성이 높은 제품을 접했을 때 피부전도율의 증가 경향도 두 드러지는 것으로 나타났다. 실험 참가자의 평균 증가 비율이 전체 신호폭의 약 $38 \%$ 를 기록했으며, 이러한 증가 경향이 심미성 고집 단 참여자 30 명 중 23 명에서 일관성 있게 나타남을 관찰할 수 있 었다. 따라서 피부전기도의 상승이 심미성이 높은 제품의 외관에 기인함을 의미한다고 볼 수 있다.

\section{4. 생리적 측정치와 주관적 평가의 비교}

패션제품에 대한 생리적 반응과 주관적 심미성 측정치 간 연관 성을 분석하여 웨어러블 기기의 측정 가능성을 탐색하였다. 분석 을 위해 먼저, 자기기입식 설문에 의한 심미성 측정 신뢰도를 검증 하였다. 측정 문항의 크론바하 알파값(Cronbach's $\alpha$ )은 0.84로 나 타나 문항의 내적 일관성을 보여주었다. 이후 패션제품에 대한 심 미성 평가 문항의 개인별 평균값을 종속변수로 하고, 생리적 반응 에 대한 측정값을 독립변수로 하여 생리적 반응으로 심미성 평가 를 예측할 수 있는 회귀분석을 실시하였다.

Table 6에서와 같이 피부전도도가 설문으로 측정된 심미성 평 가에 영향을 미치고 있음이 확인되었으나, 심박수의 영향은 유의 미하지 않은 것으로 나타났다. 회귀분석과 함께 패션제품의 심미 성 척도에 대한 생리적 반응의 상관관계를 확인하기 위해 상관계 수를 확인하였으며, 회귀분석과 동일한 결과가 도출됨을 확인하였 다. 추가적으로, 제품 선호에 생리학적 데이터가 미치는 영향을 분 석하였다. 이 분석에서는 심박수의 변산도 선호를 예측할 수 있는 것으로 나타났다. 심박수 자체로는 심미성 평가나 제품 선호를 예 측할 수 없지만, 심박수의 변화는 제품에 대한 선호를 어느 정도 예측하는 결과를 나타내었다. 이와 같은 결과가 나타난 것을 제품 을 지각하는 과정과 연관하여 설명할 수 있을 것이다. 소비자는 제 품의 외관에 대해 미적으로 아름답다고 생각하더라도 흥미를 느끼 지 못하면 심박수는 증가하지 않는 것으로 볼 수 있다.

본 연구의 결과에서 볼 때 웨어러블로 측정한 생리적 데이터는 제품의 심미성을 어느 정도 예측하는 것으로 결론지을 수 있다. 선 행 연구에 의하면, 인간의 오감 중 시각이 심미적 감성을 유발하
는 데 특히 강력한 작용을 한다고 한다((Lindstrom, 2005). 본 연 구에서도 제품 형태에 의한 시각적 자극이 심미성을 유발함이 증 명되었다. 이는 제품, 점포, 웹사이트, 광고 디자인의 시각적 이미 지가 소비자의 심미적 반응을 이끌어낸다는 다수의 연구결과(Lee et al., 2011; Lee et al., 2018; Jang et al., 2015; Tuch et al., 2010)와 맥락을 같이 하는 결과이다. 또한 본 연구의 생리적 측정 결과는 예술작품이나 사진을 감상할 때의 심미적 체험을 심박수로 설명할 수 있음을 밝힌 Nakahara et al. (2009)의 연구나 피부전 기활동 증가로 증명한 Koelsch \& Siebel (2005)의 연구와도 일맥 상통하는 결과라 볼 수 있다.

선행연구와 본 연구가 차별되는 점은 연구 결과에서는 제품 심 미성 고저에 따른 심박수나 심박수 변산의 변화 자체는 관찰되지 않았고, 심미성과 선호의 상호작용을 확인하였다는 점이다. 피부 전기도 반응의 유의미한 결과를 제외하고 심박수 결과만을 고려할 때, 제품의 심미성 자체는 생리적 반응을 유도할 수준의 자극은 되 지 않으나 소비자의 선호를 반영한 아름다운 제품은 소비자 반응 을 이끌어낸다는 결론을 내릴 수 있다. 이러한 결과가 도출된 배 경을 생리학적 측정 방법의 양가성(valence) 반영이라는 측면에서 검토해 보아야 한다. 다수의 연구에서 심미성 반응이 심박수의 변 화를 야기한다고 보고하고 있으나, 일부 연구자는 심박수가 각성 상태만을 반영함을 밝히고 있다(Park, 2011). 이는 긍정적(+), 부 정적(-) 각성 모두 심박수의 변화를 유발할 수 있으므로 심미성이 극단적으로 낮은 상태, 즉 미적 추함을 지각하였을 때에도 심박수 가 증가할 가능성을 염두에 두어야 하며, 양가성을 판단하기 위해 서는 다른 측정치를 함께 고려해야 함을 의미한다.

본 연구에서 심장 활동의 유의미한 변화는 심미성과 선호가 모 두 높은 제품에서만 관찰되었음을 주목할 필요가 있다. 응답자의 긍정적 반응에서만 심박수의 변화를 확인한 것은 심미성이 유발하 는 긍정적 각성 상태로 볼 수 있다. 생리적 데이터로 심미성 지각 을 측정하는 기존 연구에서 나아가 제품에 대한 선호를 반영함으 로써 심미성 지각의 방향성을 추론할 수 있는 근거를 마련한 것이 다. 이를 통해 기존의 심미성 측정 연구를 확장했다 할 수 있다.

심박수 외에도 심미성 수준에 따라 피부 전기 반응에 차이를 보

Table 6. Results of regression analysis on perceived aesthetics and preference

\begin{tabular}{lcc}
\hline Independent variables & Dependent variables & \\
\cline { 2 - 3 } Heart rate & Perceived aesthetics & Preference \\
Variability of heart rate & 0.06 & 0.10 \\
$\mathrm{SCL}$ & 0.09 & $0.18^{*}$ \\
Variability of SCL & $0.20^{*}$ & $0.32^{*}$ \\
$\mathrm{R}^{2}$ & $0.29^{*}$ & $0.38^{*}$ \\
\hline
\end{tabular}

${ }^{*} p<0.05$; SCL, skin conductance level; $\mathrm{R}^{2}$, explanatory power of the regression model. 
이는 것은 유의미한 결과이나, 이 결과를 현장에 적용하기 위해서 는 후속 연구가 축적되어야 할 것으로 생각된다. 웨어러블은 정교 한 생리적 측정도구에 비해 측정의 한계가 있다. 안정된 상태와 운 동 시 심박수 차이는 웨어러블에 의해 측정된 값에도 분명한 차이 를 찾아볼 수 있지만, 본 연구에서처럼 심미적 자극에 의한 차이 는 미미할 가능성이 있다. 또한 땀의 배출을 근거로 측정하는 피부 전기도는 외부의 시각적 자극 외에도 온도나 기온, 심리상태에 따 라 변화할 수 있는 수치이다. 따라서, 심미성 반응의 측정 정확도 를 높이기 위한 노력이 뒤따라야 할 것이다. 심박수와 피부전기도 를 결합하여 제품에 대한 심미성 평가를 측정할 수 있는 별도의 지 표를 개발하거나, 제품 브라우징 시간 등 다른 객관적 데이터를 심 미성 지각의 예측 변수로 투입하는 방법도 생각해 볼 수 있다. 이 외에도 본 연구에서 심미성 조작을 위해 이용된 독특성 외 다른 디 자인 요소에 의해서 심미성을 유발할 수 있는 지도 확인되어야 한 다. 제품의 독특성이 심미성 평가에 영향을 주는 것은 기존의 연구 를 통해 밝혀졌지만, 또 다른 선행 연구에 의하면 사람들은 익숙한 것에서 아름다움을 느끼기 쉽다고 한다. 따라서 특정 소비자에게는 독특성보다는 친숙성에 의해 심미성이 유발될 수도 있다. 심박수나 피부전기도의 증가를 유도하는 것이 정확히 제품의 어떤 요인인 지 를 지속적으로 탐구하고, 심미성 반응을 추론할 수 있는 대체 지표 들을 활용하여 소비자 반응을 설명하려는 노력을 지속함으로써 소 비자에 대한 이해의 폭을 넓힐 수 있을 것이다.

\section{Conclusion}

이상에서 제품의 외형적 요소, 즉 디자인이 불러 일으키는 심미 성 반응을 웨어러블 기기로 측정하여 전통적 측정방법인 자기 기 입식 설문에 의한 측정과 비교하였으며, 두 측정 방법의 상관 정 도를 밝혔다. 연구 결과, 제품 형태의 독특성으로 심미성의 고저 가 조작된 자극물에 대해 응답자의 심박수나 심박수 변산 차이는 존재하지 않았다. 그러나, 심미성과 응답자의 선호가 일치하는 제 품, 즉 심미성 수준과 선호가 모두 높은 제품과 심미성 수준과 선 호가 모두 낮은 제품들에 있어서는 심박수 변산의 차이가 존재하 여, 심미성과 선호가 높은 제품에 대해서는 심박수 변산이 확대되 었음을 확인하였다. 또한 심미성이 높은 제품이 피부 전기도를 더 크게 상승시키며, 피부 전기도 반응과 심미성에 대한 주관적 평가 가 관련 있음도 확인되었다.

이상의 연구 결과를 통해 학문적, 사회적, 교육적 기여점과 활 용 방안을 모색해 볼 수 있을 것이다. 본 연구는 제품의 구매의사 결정과정 연구를 확장하는 데 기여할 것이다. 뷰티 제품의 감성 적 반응은 주로 주관적 기입에 의해 측정되었으나, 본 연구에서는 심미성이라는 감성적 반응을 생리학적 방법으로 측정하였다. 이 는 제품을 접하는 시점과 측정 시점의 거리가 먼 사후 측정을 보
완할 수 있음을 의미한다. 즉, 제품 초기 접점에서 소비자의 흥미 유발 여부를 판단할 수 있기 때문에, 문제인식 단계의 소비자 행 동에 있어 그간 밝혀지지 않았던 영역을 확장할 수 있을 것으로 생각된다. 또한 감성은 인지적, 행위적 반응에 영향을 미치므로 (Scherer, 1984), 문제인식 단계에서 유발된 감성이 소비자 의사 결정과정의 이성적 탐색과 판단에 이르는 과정을 이해하는 데에도 기여할 것이다.

웨어러블이라는 새로운 측정 방법에 도전한 점에서도 의의를 찾을 수 있다. 빠르게 변화하는 기술 환경을 수용하여, 기존의 복 잡한 장치에 의존했던 생리적 데이터 측정을 보다 간소화할 수 있 는 방안을 모색하는데 기여할 것으로 생각된다. 본 연구에서 시 도된 측정 방법을 다른 제품군이나 연구 영역으로 확대할 수 있을 것이다.

본 연구 결과는 산업계에도 시사점을 줄 수 있을 것이다. 착용 자의 생리적 데이터를 측정할 수 있는 웨어러블 기기는 대부분 사 용자의 위치도 추적하는 기능도 갖출 수 있다. 따라서 소비자가 제품에 대해 느끼는 감정과 위치 정보를 종합하여 보다 개인화된 타겟 마케팅을 전개할 수 있을 것이다. 예를 들어, 주변 상점이나 제품에 대해 일괄적으로 할인 쿠폰을 제공하는 현재의 서비스 수 준에서 나아가, 소비자 주변의 제품 중에서도 흥미를 느끼는 제품 들에 대해서만 쿠폰을 제공할 수 있다. 이러한 타겟 마케팅은 앞 으로 더 정교하고 진보된 웨어러블 기기가 사용화되면 빛을 발할 수 있을 것으로 기대된다.

교육과 연계된 활용 방안도 생각해볼 수 있다. 소비자 반응 분 석에 본 연구에서 도입한 기술적 시각을 교육 과정에 이용하는 것 이다. 제품 디자인 관련 교과과정에서 제품 외관에 대한 미적 평 가에 본 연구의 측정방법을 도입하면 실제 소비자들의 반응을 관 찰할 수 있다. 특히 패션제품 평가 시에는 타인의 착용 모습을 직 접적으로 평가하는데 부담을 느끼기 쉽다. 그러나 웨어러블 기기 를 통한 측정으로 반응을 알아내는 것이 가능해지면 제품 디자인 에 반영하기 용이해 진다. 이를 통해 학생들은 소비자의 반응에 기반하여 미적으로 아름다운 제품을 구현할 수 있으며, 소비자 친 화적인 시각을 훈련할 수 있을 것이다. 이러한 교육 프로그램은 향후 산업계 인력을 대상으로 한 실무형 강의로 확대 가능하며, 향후 기술·공학과 패션의 융합 교육과정 개설에 초석이 될 수 있을 것이다.

\section{Acknowledgements}

This work was supported by the Ministry of Education of the Republic of Korea and the National Research Foundation of Korea (NRF-2016S1A5B5A07920508).

\section{Author's contribution}

JP alone contributed to this work. The author designed all 
experiments, performed a pre-test, and collected analyzed and interpreted the data regarding physical and written responses. The author also wrote the manuscript and oversaw the project.

\section{Author details}

Jisoo Park (Administrative assistant), Research Institute of Human Ecology, Seoul National University, 1 Gwanakro, Gwanak-gu, Seoul 08826, Korea

\section{References}

Bloch PH. Seeking the ideal form: product design and consumer response. Journal of Marketing, 59: 16-29, 1995.

Bollen D, Knijnenburg BP, Willemsen MC, Graus M. Understanding choice overload in recommender systems, proceedings of the fourth ACM conference on Recommender systems. ACM New York, New York, pp63-70, 2010.

Cacioppo JT, Tassinary LG. Inferring psychological significance from physiological signals. The American Psychologist, 45: 16-28, 1990.

Davis G. Prolonging the pleasure. Taylor \& Francis, London, pp307-312, 2003.

Garber LL. The role of package appearance in choice. Advances in Consumer Research, 22: 653-660, 1995.

Han SY, Cho YJ, Lee YR. The effect of the fashion product classification method in online shopping sites. Journal of the Korean Society of Clothing and Textiles, 40: $287-$ 304, 2016.

lyengar SS, Lepper MR. When choice is demotivating: Can one desire too much of a good thing? Journal of Personality and Social Psychology, 79: 995-1006, 2000.

Jang HY, Jeong HJ, Kim JJ. The effect of the vmd cognition dimensions of fashion stores on consumers' emotional responses and purchase intention. Journal of Business Research, 30: 427-452, 2015.

Jeong KY, Seo MK. A study on the effect of Chinese consumers' emotional consumption values on the relationship quality between consumers and Korean cosmetics brands. Journal of Business Research, 31:
333-365, 2016.

Jin HR, Kim MN, Song SM, Kwon TK, Yu M, Jin BD, Hong JP. Development of emotional lighting system on the evaluation of humen-body effect of color lighting mode. Archives of Design Research, 23: 59-68, 2011.

Ju SH, Koo DM. Effect of the characteristics of art collaboration products on customers' perceived value and product purchasing intention. Journal of Marketing Studies, 22: 101-123, 2014.

Ju SH. The characteristics of art collaboration product affect consumer's emotion: the moderatating effects of need for uniqueness. Journal of Marketing Management Research, 17: 47-77, 2012.

Kang HT. The influence of perceived aesthetics and corporate association on user behavior. Journal of International Trade \& Commerce, 12: 539-556, 2016.

Kim BY, Koo TY, Bae CH, Park CH, Seo MW. A study on $\mathrm{HMI}$ assessment of joystick driving system using the physiological signal measurement method. Transactions of the Korean Society of Automotive Engineers, 18: 1-7, 2010.

Kim MK. Brain recognition and sensibility response according to the shape of eyes and eyeshadow tone. Asian Journal of Beauty and Cosmetology, 15: 421434, 2017.

Kim YS. Influence which emotion valuation criteria of product design have over users satisfaction and users loyalty: with a smart phone as the object. $A$ Journal of Brand Design Association of Korea, 11: 257-268, 2013.

Koelsch S, Siebel WA. Towards a neural basis of music perception. Trends in Cognitive Sciences, 9: 578-584., 2005.

Koo HR, Lee YJ, Gi S, Lee SP, Kim KN, Kang SJ, Lee JH. Effect of module design for a garment-type heart activity monitoring wearable system based on non-contact type sensing. Journal of the Korean Society of Clothing and Textiles, 39: 369-378, 2015.

Kotler P. Atmospherics as a marketing tool. Journal of Retailing, 49: 48-65, 1973.

Kwak HR, Kim BM, Son YW. Aesthetics versus usability: Cultural difference in product choice. Korean Journal of the Science of Emotion \& Sensibility, 14: 361-370, 2011.

Lee HK, Ahn S, Choo HJ. The effect of creative store display 
on creative consumption behavior: focusing on the mediation role of creative consumer efficacy. Journal of Consumer Studies, 29: 77-95, 2018.

Lee JH, Lee KP. The method for measuring the initial stage of emotion in use context. Korean Journal of the Science of Emotion \& Sensibility, 13, 111-120, 2010.

Lee JM. A study on the psychological correlation between aesthetic design and user's self: focused on aesthetic design's influence regarding various types of human self. Journal of Korea Design Forum, 41: 389-402, 2013.

Lee KH, Lee SS, Kim SM, Lee HJ, Min KJ, Kang HK, Lee JH, Kwak HK, Ko YS, Lee JH. A study on the correlationship between wearable ecg and clinical ecg measurements. The Transactions of the Korean Institute of Electrical Engineers, 67: 1690-1698, 2018.

Lee NK, Park OL. Effect of women's cosmetics shopping tendency according to age on brand attittude. Asian Journal of Beauty and Cosmetology, 12: 55-67, 2014.

Lee SE. Effect of visual images of low-cost cosmetics on consumer types and their behaviors. Asian Journal of Beauty and Cosmetology, 14: 30-41, 2016.

Lee SH, Kim KH, Ahn JA, Chung IH. Analysis for communication research using psychophysiological measures in Korea and the United States: focused on heart rate, facial emg and skin conductance. The Korean Journal of Advertising, 22: 7-27, 2011.

Lee SM, Lim CH. A study on package design and illustration for eco-friendly organic cosmetics. Illustration Forum, 32: 15-26, 2012.

Lee SY, Min DW. How eco-friendly message affects attitudes and purchase intention in cosmetic: focused on moderating effects of packaging transparency and ecoinvolvement. Journal of Product Research, 33: 99-110, 2015.

Lim BW. A study on factors of purchasing decisions and colors of package design into organic cosmetics. Illustraion Forum, 47: 71-80, 2016.

Lim SJ, Park, SE. A study of the influence of the attribute perception of clothing upon preference and purchase intentions. Journal of the Korean Society of Clothing and Textiles, 23: 929-940, 1999.

Lindstrom M. Brand sense: how to build powerful brands through touch, taste, smell, sight and sound. Kogan
Page, London, pp138-164, 2005.

$\mathrm{Na} \mathrm{D}$, Chung JE, Cha M. The effects of product visibility, price, and individual differences in the centrality of visual product aesthetics on consumers' purchase intentions and postpurchase evaluations under aesthetic versus functional trade-off contexts. Journal of Consumption Culture, 20: 207-233, 2017.

Nakahara H, Furuya S, Obata S, Masuko T, Kinoshita H. Emotion-related changes in heart rate and its variability during performance and perception of music. Annals of the New York Academy of Sciences, 1169: 359-362, 2009.

Nam DH. Validity and reliability of the wearable body composition measurement tool (InBody BAND). The Korean Journal of Measurement and Evaluation in Physical Education and Sports Science, 18: 59-69, 2016.

Norman D. Emotional design: why we love (or hate) everyday things. Basic Books, New York, pp29-33, 2005.

Park JS. Effects of sounds on user experiences in digital games. Journal of Digital Design, 11, 139-148, 2011.

Patrick V, Hagtvedt $\mathrm{H}$. Aesthetic incongruity resolution. Journal of Marketing Research, 48: 393-402, 2011.

Ravaja,N. Effects of image motion on a small screen on emotion, attention, and memory: moving-face versus static-face newscaster. Journal of Broadcasting \& Electronic Media, 48: 108-133, 2004.

Ryu JS, Lee JS. Correlation analysis of emotional adjectives and EEG to apply color to the indoor living space. Journal of Korean Society of Color Studies, 29: 25-35, 2015.

Scherer KR. On the nature and function of emotion: a component process approach. In: Approaches to emotion. Scherer K, Ekman P (eds.) Psychology Press, New York, p2293, 1984.

Sequeira H, Hot P, Silvert L, Delplanque S. Electrical autonomic correlates of emotion. International Journal of Psychophysiology, 71: 50-56, 2009.

Shin MS, Lee YJ. A study on the influential factors of purchase intention of wrist wearable device. The Journal of the Korea Contents Association, 15: 498-506, 2015.

Song YH, Lee YH. A study on color trends in perfume package design. A Journal of Brand Design Association of Korea, 10: 159-170, 2017. 
Thayer JF, Hansen AL, Saus-Rose E, Johnsen BH. Heart rate variability, prefrontal neural function, and cognitive performance: The neurovisceral integration perspective on self-regulation, adaptation, and health. Annals of Behavioral Medicine, 37: 141-153, 2009.

Tröndle M, Greenwood S, Kirchberg V, Tschacher W. An integrative and comprehensive methodology for studying aesthetic experience in the field: merging movement tracking, physiology, and psychological data. Environment and Behavior, 46: 102-135, 2014.
Tuch AN, Bargas-Avila JA, Opwis K. Symmetry and aesthetics in website design: it's a man's business. Computers in Human Behavior, 26: 1831-1837, 2010.

Underwood R. The communicative power of product packaging: creating brand identity via lived and mediated experience. The Journal of Marketing Theory \& Practice, 11: 62-76, 2003.

Yang JY, Hong JP. The influence of aesthetic elements on emotional responses to perfume bottle design. Archives of Design Research, 12: 129-140, 1999. 
국문초록

\section{패션제품에 대한 심미성 반응 측정도구로서 웨어러블의 가능성 탐구}

박지수

서울대학교 생활과학연구소, 서울, 한국

목적: 본 연구는 제품 외관의 심미성 변화(고 vS. 저)에 따른 생리적 반응을 정량적으로 측정하고 자기기입식 설문에 대한 응답과의 상관관계를 파악함으로써 소비자 반응의 새로운 측정도구로서 웨어러블의 가능성을 탐색하고 향후 과학적 데이터로 활용하는 방안 을 제시하고자 한다. 방법: 향수 제품을 대상으로 외관의 심미성이 높은 제품과 낮은 제품을 자극물로 개발한 후, 참가자를 심미성 고/저 자극물에 무작위로 배정하여 웨어러블 기기와 자기기입식 설문으로 심미성 지각 반응을 측정하였다. 결과: 심미성 고저에 따 른 심박수, 심박수의 변산의 차이는 통계적으로 유의미하지 않았으나, 제품에 대한 선호와 심미성 고저의 상호작용이 확인되어 심 미성이 높고 개인의 선호에도 부합하는 제품은 심박수 변산을 확대함이 관찰되었다. 심미성이 높은 제품은 낮은 제품에 비해 피부 전도도의 상승을 더 많은 유발하는 것으로 나타났다. 생리적 데이터 중 피부전도도만이 심미성 지각에 대한 주관적 평가와 상관관 계가 있음이 확인되었다. 결론: 심미성에 차이를 보이는 제품들에 대한 생리적 반응에도 차이를 보이고, 자기기입식 설문과의 연관 성이 관찰됨에 따라 웨어러블 기기의 심미성 반응 측정 가능성을 확인할 수 있었다. 향후 다양한 제품군으로 결과를 확대하고, 소비 자를 대상으로 타겟 마케팅을 수행하는 데 활용할 수 있을 것으로 사료된다.

핵심어: 심미성, 웨어러블, 심박수, 피부전도도, 생리적 측정

이 논문은 2016년 대한민국 교육부와 한국연구재단의 지원을 받아 수행된 연구임 (NRF-2016S1A5B5A07920508).

\section{참고문헌}

강희택. 지각된 심미성과 기업연상이 사용자 행동에 미치는 영향. 무역연구, $12: 539-566,2006$.

곽해리, 김봄메, 손영우. 심미성과 사용성: 제품 선택에서의 문화차. 감성과학, $14: 361-370,2011$.

구혜란, 이영재, 지선옥, 이승표, 김경남, 강승진, 이정환, 이주현. 비접촉식 심장활동 모니터링 기능 의복형 웨어러블 시

스템의 모듈 효과 탐색. 한국의류학회지, 39: 369-378, 2015.

김민경. 눈의 형태와 아이쉐도우 톤 변화에 따른 뇌 인지와 감성반응. 아시안뷰티화장품학술지, 15: 421-434, 2017. 김배영, 구태윤, 배철호, 박정훈, 서명원. 생리신호 측정기법을 이용한 Joystick 운전방식의 HMI 평가연구. 한국자동차공

학회논문집, $18: 1-7,2010$.

김영석. 제품디자인의 감성평가기준이 사용자 만족도와 사용자 충성도에 미치는 영향: 스마트폰을 대상으로. 브랜드디자

인학연구, 11: 257-268, 2013

나다혜, 정재은, 차민정. 제품의 가시성 및 가격과 소비자의 심미적 성향이 소비자 구매의도와 구매 후 평가에 미치는 영

향: 심미성·기능성이 상충되는 상황을 중심으로. 소비문화연구, 20: 207- $233,2017$.

남덕현. 웨어러블 신체구성 측정기기(InBody BAND)의 타당도 및 신뢰도 검증. 한국체육측정평가학회지, 18: 59-69, 2016.

류지선, 이진숙. 실내거주공간의 적용색채에 따른 감성어휘와 뇌파의 상관관계 분석. 한국색채학회논문집, 29: 25-35, 2015.

박정순. 디지털 게임에서 소리(Sound)가 사용자 경험에 미치는 영향. 디지털디자인학연구, 11: 139-148, 2011. 송연호, 이영화. 향수 패키지디자인에 나타난 색채 트랜드 연구. 브랜드디자인학연구, 10: 159-170, 2017.

신명섭, 이영주. 손목형 웨어러블 디바이스 구매의도에 영향을 미치는 요인에 관한 연구. 한국콘텐츠학회논문지, 15 : 
498-506, 2015.

양종열, 홍정표. 제품 디자인에 있어서 감정적 반응에 대한 심미적 요소의 영향. 디자인학연구, $12: 129-140,1999$.

이강휘, 이성수, 김상민, 이혁재, 민경진, 강현규, 이주현, 곽휘권, 고윤수, 이정환. 웨어러블 심전도 측정과 임상 심전도

측정과의 상관관계에 대한 연구. 전기학회논문지, 67: 1690-1698, 2018.

이나겸, 박옥련. 여성의 연령별 화장품 쇼핑성향이 브랜드태도에 미치는 영향. 아시안뷰티화장품학술지, 12: 55-67, 2014.

이상연, 민동원. 화장품 패키징에 있어 친환경 알림과 투명도의 영향: 관여도의 조절효과를 중심으로. 상품학연구, 33 : 99-110, 2015.

이상은. 저가화장품 시각적 이미지가 소비자유형과 구매행동에 미치는 영향. 아시안뷰티화장품학술지, 14: 30-41, 2016. 이선미, 임채형. 친환경 유기농 화장품 패키지디자인과 일러스트레이션에 관한 연구. 일러스트레이션 포럼, 32: 15-26, 2012.

이시훈, 김광협, 안주아, 정일형. 심리생리적 측정방법을 이용한 한국과 미국의 커뮤니케이션 연구 분석: 심장혈관계, 근 육, 피부 측정을 중심으로. 광고학연구, 22: 7-27, 2011.

이재화, 이건표. 제품 사용 환경의 사용자 초기 감성 측정 방법에 관한 연구. 감성과학, 13: 111-120, 2010.

이정민. 디자인의 심미성과 사용자 자아의 심리학적 연관성에 관한 연구: 자아 유형별 심미적 디자인의 영향력 분석을 중 심으로. 한국디자인포럼, 41: 389-402, 2013.

이하경, 안서원, 추호정. 창의적 매장 디스플레이가 창의적 소비행동에 미치는 영향: 창의적 소비효능감의 매개 효과를 중 심으로. 소비자학연구, 29: 77-95, 2018.

임병우. 유기농 화장품 구매 요인과 포장디자인 색채에 관한 연구. 일러스트레이션 포럼, 47: 71-80, 2016.

임숙자, 박성은. 의복의 속성 지각이 의류 제품이 선호와 구매 의도에 미치는 영향 : 여대생의 의복 관여를 중심으로. 한국 의류학회지, 23: 929-940, 1999.

장희영, 정효진, 김재진. 패션 매장 $\mathrm{VMD}$ 의 인지차원이 소비자의 감정반응과 구매의도에 미치는 영향. 경영연구, 30 : 427-452, 2015.

정갑연, 서민교. 중국소비자의 감성적 소비가치가 한국 화장품 브랜드와의 관계의 질에 미치는 영향. 경영연구, $31: 333-$ 365, 2016.

주선희. 아트 콜라보레이션 제품의 특성이 소비자의 감정에 미치는 영향: 독특성 추구성향 조절효과 중심으로. 마케팅관리 연구, 17: 47-77, 2012.

주선희, 구동모. 아트 콜라보레이션 제품의 특성이 소비자의 지각된 가치와 제품 구매의도에 미치는 영향. 마케팅논집, 22: 101-123, 2014.

진혜련, 김미나, 송성미, 권대규, 유미, 진배동, 홍정표. 컬러모드의 인체 영향 평가를 통한 감성조명 시스템 개발. 디자인 학연구, 23: 59-68, 2011.

한서영, 조윤진, 이유리. 인터넷 쇼핑몰의 패션 제품 분류 방식의 효과. 한국의류학회지, 40: 287-304, 2016. 


\section{中文摘要}

\section{时尚产品的审美反应测定工具Wearables的可行性研究}

朴志修

首尔大学生活科学研究所, 首尔, 韩国

目的: 本研究通过根据产品外观定量测量对美学差异（高与低）的生理反应，探索Wearables设备作为衡量消费 者对产品反应的新工具的潜力；我们还检查了生理测量值与自我报告的反应之间的相关性。方法: 在将香料产品 用作刺激剂后, 我们根据其高低审美的方面将它们分为两组。此外, 我们将参与者随机分配到这两个组之一。 汶览产品时, 根据对香水美学的看法, 参与者使用Wearables设备测量其心跳和皮肤电反应。我们还通过自我报 告的调查收集了参与者的反馈。结果: 心率和心率变异性对感知美感的反应差异无统计学意义。但是, 我们确实 观察到了产品偏好与感知美学之间的相互作用。通过调查发现, 具有较高美学和个人偏爱的产品引起更大的心 率变异性：此类产品还倾向于引起更多的皮肤电反应。在生理数据中，发现皮肤电导率与感知美感的主观评估 最相关。结论：我们确认生理反应根据产品外观的美学水平而有所不同，并且与自我报告的感知美学一致。这些 结果可以扩展到各种产品组，并用于对消费者进行营销。

关键词：审美性，Wearables，心率，皮肤电导率，生理测量 
